\title{
HUBUNGAN MENCARI SENSASI DENGAN PERILAKU PENGENDARA BERESIKO PADA REMAJA
}

\author{
Jem Ulina Purba ${ }^{1}$, Husnan $^{2}$, Abdurrahman Hamid ${ }^{3}$ \\ ${ }^{2}$ Jurusan Keperawatan Poltekkes Kemenkes Riau, ${ }^{1,3}$ Program Studi Ilmu Keperawatan \\ STIKes Hang Tuah Pekanbaru
}

\begin{abstract}
ABSTRAK
Perilaku pengendara beresiko adalah istilah yang diberikan kepada pengendara yang meningkatkan resiko terjadinya kecelakaan lalu lintas. Penelitian ini bertujuan untuk mengatahui hubungan sikap mencari sensasi dengan perilaku pengendara beresiko pada remaja. Desain yang digunakan dalam penelitian ini adalah desain analisis korelasi dan menggunakan pendekatan cross sectional, sampel dalam penelitian ini sebanyak 126 responden, teknik pengambilan sampel menggunakan random sampling, analisis yang dilakukan adalah analisis univariat, dan bivariat. Hasil penelitian menunjukkan, remaja yang memiliki perilaku mengemudi beresiko tinggi sebanyak 72 orang $(57,1 \%)$, setelah dilakukan analisis bivariat,mencari sensasi berhubungan dengan perilaku pengendara beresiko, P-value 0,024. Dapat disimpulkan bahwasikap mencari sensasi pada remaja secara statistik berhubungan dengan perilaku pengendara beresiko. Diharapkan pihak sekolah agar membimbing siswa dan siswi untuk menyalurkan energi mencari sensasi ke hal yang positif seperti, mengikuti eskul di sekolah, seperti eskul olahraga, seni, atau pada pelajaran yang non akademik.

Kata kunci: Perilaku Pengendara Beresiko, Mencari Sensasi, Remaja.
\end{abstract}

\section{PENDAHULUAN}

Perilaku pengendara beresiko adalah istilah yang diberikan kepada pengendara yang meningkatkan resiko terjadinya kecelakaan, seperti membawa kendaraan dengan kecepatan tinggi, melanggar peraturan lalu lintas saat berkendara, dan sikap beresiko yang berkaitan dengan keselamatan saat berkendara (Yilmaz \& celik, 2006).

World Health Organization menyebutkan pada tahun 2015 dari 180 negara, menunjukkan bahwa diseluruh dunia jumlah total angka kematian kecelakaan lalu lintas di jalan sebanyak 1,25 juta pertahun, dengan tingkat kematian tertinggi di negara-negara berpenghasilan rendah. Negara dengan kematian terbanyak akibat kecelakaan lalu lintas dan yang menempati urutan pertama adalah India Sedangkan indonesia menduduki urutan kelima setelah Cina, Nigeria dan Brazil (WHO, 2015).

Di Indonesia pada tahun 2015 menurut Badan Pusat Statistik Indonesia (BPS) jumlah kasus kecelakaan lalu lintas mencapai 98.970 kasus. Korban meninggal dunia sebanyak 26.495 orang, luka berat 23.937 orang, dan luka ringan sebanyak 110.714 orang. Sedangkan pada tahun 2016 jumlah kasus kecelakaan lalu lintas mencapai 106.129 kasus dengan korban meninggal dunia sebnyak 26.185 orang luka berat 22.558 dan luka ringan sebanyak 121.550 orang. Terjadi peningkatan kasus kecelakaaan lalu lintas di tahun 2016 sebanyak 7,23\% dibandingkan dengan tahun 2015 (BPS, 2016).

Sedangkan angka kecelakaan lalu lintas di Kota Pekanbaru pada tahun 2017 berjumlah 191 kasus, dengan 
korban meninggal dunia 82 orang, luka berat 93 orang, dan luka ringan 164 orang (Satlantas Pekanbaru, 2017). Terjadinya kecelakaan lalu lintas berkaitan dengan pengendara beresiko, timbulnya kecelakaan lalu lintas tidak lain akibat dari pengemudi yang mengendarai kendaraan penuh resiko atau bisa dikatakan tidak mematuhi aturan rambu lalu lintas. Penelitian yang dilakukan oleh Yogatama (2013) menyebutkan bahwa kendaraan yang sering mengalami kecelakaan adalah pengendara sepeda motor yang melanggar aturan rambu lalu lintas, khususnya pengendara yang tidak menggunakan helm.

Kecelakaan lalu lintas menyebabkan korban menderita berbagai jenis luka dan cacat, yang dapat mempengaruhi kualitas hidup mereka dan korban juga mengalami gangguan fisik, mental dan sosial. Kebanyakan korban mengalami kesulitan untuk kembali kekehidupan normal (Sabet et al, 2016).

Masa remaja termasuk masa yang sangat menentukan karena pada masa ini anak-anak mengalami perubahan psikis dan fisiknya. Terjadinya perubahan kejiwaan menimbulkan kebingungan dikalangan remaja sehingga masa ini disebut oleh orang berat sebagai periode strum und drang. Karena pada masa remaja mereka mengalami perubahan emosi dan sehingga mereka mudah untuk melanggar atau menyimpang dari aturan dan norma-norma sosial yang berlaku dikalangan masyarakat (Zulkifli, 2009).

Hasil penelitian Handayani et al (2017) memperlihatkan bahwa; remaja pengendara sepeda motor di Kota Surakarta yang memiliki SIM C hanya sebagian, masih banyak remaja yang sudah mengendarai motor namun belum berusia 17 tahun, ada juga remaja mengendarai dengan kecepatan di atas ambang batas, dan melanggar lampu dan rambu lalu lintas jalan raya.

Secara umum faktor yang mempengaruhi perilaku pengendara beresiko adalah kecemasan, marah, mencari sensasi, kognitif, altrusm, dan normlessness (Chen, 2009). Hasil penelitian yang dilakukan Agung (2014) menemukan bahwa variabel mencari sensasi, sikap terhadap pengendara berisiko dan persepsi risiko yang konsisten berperan terhadap perilaku pengendara beresiko pada remaja, dan cemas juga berhubungan signifikan dengan perilaku pengendara beresiko.

Penelitian yang dilakukan Bagaskara (2017) memperlihatkan adanya hubungan antara perilaku mengemudi beresiko dengan mencari sensasi. Sedangkan hasil penelitian Deffenbacher et al (2003) menyebutkan pengendara yang dengan kemarahan tinggi lebih sering mengalami marah dan juga lebih banyak agresif.

Dalam penelitian ini akan lebih berfokus pada sikap mencari sensasi pada remaj dengan perilaku pengendara beresiko.

\section{METODE PENELITIAN}

Jenis penelitian ini adalah penelitian kuantitatif dengan desain analisis korelasi dan menggunakan pendekatan cross sectional. Responden dalam penelitian ini berjumlah 126 responden, teknik sampling yang digunakan adalah random sampling dengan teknik cluster sampling. Pengambilan data dengan cara memberikan kuesioner di empat instansi pendidikan tingkat SLTA Kota Pekanbaru yang lokasi sokolah berdekatan dengan jalan besar, sebelum kuesioner diisi oleh responden, lembar persetujuan menjadi responden harus ditandatangani terlebih dahulu. Analisis yang dilakukan adalah analisis univariat, bivariat.

\section{HASIL}

Karakteristik responden dilihat dari jenis kelamin dan usia, ditemukan bahwa distribusi frekuensi jenis kelamin dari 126 responden bahwa, mayorita jenis kelamin adalah laki-laki sebanyak 72 orang $(57,1 \%)$, minoritas adalah perempuan 54 orang $(42,9 \%)$. 
Sedangkan jika dilihat dari usia responden ditemukan bahwa umur responden dari 126 orang yang minimal adalah 15 tahun, maximal 19 tahun, dengan range 4 , mean 16,75 , mudus 17 dan dengan Standar Devisiasi 0, 748.
Pada tabel 1 dibawah ini akan menjelaskan hubungan mencari sensai dengan perilaku pengendara beresiko pada remaja.

Tabel 1 Hubungan mencari sensasi dengan perilaku pengendara beresiko pada remaja

\begin{tabular}{|c|c|c|c|c|c|c|c|c|}
\hline \multirow{2}{*}{$\begin{array}{c}\text { Mencari } \\
\text { Sensasi }\end{array}$} & \multicolumn{8}{|c|}{ Perilaku pengendara beresiko } \\
\hline & $\begin{array}{c}\text { Tinggi } \\
\mathrm{n}\end{array}$ & $\%$ & $\begin{array}{c}\text { Rendah } \\
n\end{array}$ & $\%$ & $\mathrm{n}$ & $\begin{array}{c}\text { Total } \\
\%\end{array}$ & $\mathrm{P}$ value & POR \\
\hline Tinggi & 53 & 64,6 & 29 & 35,4 & 82 & 100 & 0,024 & 2,405 \\
\hline Rendah & 19 & 43,2 & 25 & 56,8 & 44 & 100 & & $\begin{array}{l}(1,137- \\
5,085)\end{array}$ \\
\hline Total & 72 & & 54 & & 126 & & & \\
\hline
\end{tabular}

Berdasarkan tabel 1 di atas dapat dilihat bahwa dari 126 responden masih ada ditemukan sebanyak 53 orang $(64,6 \%)$ yang memiliki perilaku mencari sensasi tinggi juga memiliki perilaku pengendara beresiko kategori tinggi. Lebih dari setengah remaja yang memiliki sifat mencari sensasi tinggi mengendarai kendaraan resiko tinggi di Kota Pekanbaru.

Hasil menunjukkan bahwa mencari sensasi berhubungan dengan perilaku pengendara beresiko $\left(P_{\text {value }}=0,024 ; \alpha=\right.$ $0,05)$.

\section{PEMBAHASAN}

Berdasarkan hasil penelitian ini dapat disimpulkan bahwa ada perbedaan proporsi antara mencari sensai dengan perilaku pengendara beresiko, artinya ada hubungan antara mencari sensasi dengan perilaku pengendara beresiko. Hasil penelitian ini sejalan dengan teori Zuckerman (dalam arnett dalam Gunarsa, 2004), yang mengatakan bahwa pada masa remaja memiliki sifat perilaku beresiko, salah satunya yaitu keselamatan mengemudi, remaja yang cenderung malakukan perilaku beresiko adalah remaja yang suka dengan kesenangan mencari sensasi.
Teori ini menjelaskan bahwa pada usia remaja memang memiliki sifat yang cenderung melakukan perilaku beresiko, salah satunya yaitu keselamatan mengemudi, artinya remaja cenderung tidak memperhatikan keselamatan saat mengendarai kendaraan dengan kata lain remaja melakukan perilaku mengemudi beresiko, dan remaja yang memiliki perilaku beresiko tersebut adalah remaja yang senang terhadap sifat mencari sensasi.

Hasil penelitian ini sesuai dengan penelitian yang dilakukan Ulleberg\& Rundmo (2003) yang mengatakan bahwa mencari sensasi berhubungan dengan perilaku mengemudi beresiko. Yang artinya bahwa seseorang dengan sikap mencari sensasi tinggi akan lebih berpeluang untuk melakukan perilaku pengendara beresiko. Sama halnya dengan hasil penelitian ini menemukan bahwa ada hubungan secara statistik antara mencari sensasi dengan perilaku berkendara penuh resiko.

Bachoo et al (2013) juga mengatakan bahwa kepribadian mencari sensasi secara signifikan terkait dengan perilaku mengemudi beresiko. Hasil penelitian ini juga sejalan dengan penelitian yang dilakukan Agung (2014) bahwa variabel kepribadian mencari sensasi berhubungan 
signifikan dengan perilaku pengendara beresiko. Hasil penelitian ini memperlihatkan bahwa banyak responden yang melakukan sikap mencari sensasi yang berkaitan dengan perilaku pengendara beresiko pada pertanyaan no 10 yaitu, kesenangan dengan membawa kendaraan dengan kecepatan tinggi hal ini sesuai dengan hasil penelitian Handayani et al (2017) yang mengatakan bahwa salah satu faktor yang mempengaruhi terhadap terjadinya potensi kecelakaan adalah mengendarai dengan kecepatan tinggi sebesar 14,69\%.

\section{KESIMPULAN}

Perilaku pengendara beresiko pada remaja dominan adalah kategori tinggi 72 orang $57,1 \%$, di temukan bahwa ada hubungan antara mencari sensasi dengan perilaku pengendara beresiko pada remaja $\left(P_{\text {value }}=0,024<0,05\right.$ nilai $\mathrm{OR}=$ $2,405)$.

\section{SARAN}

Diharapkan pihak sekolah untuk membuat suatu tindakan seperti membimbing siswa dan siswi untuk menyalurkan energi mencari sensasi ke hal yang positif seperti, mengikuti ekstra kulikuler di sekolah, seperti olahraga, seni, atau pada pelajaran yang bersifat non akademik.

\section{DAFTAR PUSTAKA}

Agung, I. M. (2014). Model pengendara berisiko pada remaja. Jurnal Psikologi Integratif, 2(2).

Bachoo, S., Bhagwanjee, A., \& Govender, K. (2013). The influence of anger, impulsivity, sensation seeking and driver attitudes on risky driving behaviour among post-graduate university students in Durban, South Africa. Accident Analysis \& Prevention, 55, 67-76.

Bachoo, S., Bhagwanjee, A., \& Govender, K. (2013). The influence of anger, impulsivity, sensation seeking and driver attitudes on risky driving behaviour among post-graduate university students in Durban, South Africa. Accident Analysis \& Prevention, 55, 67-76.

Bagaskara, S. (2017). Perbandingan perilaku mengemudi berisiko antara pengemudi mobil dan pengendara sepeda motor dan kaitannya dengan faktor-faktor kepribadian. Jurnal Transportasi, 17(2).

Chen, C. F. (2009). Personality, safety attitudes and risky driving behaviors-Evidence from young Taiwanese motorcyclists. Accident Analysis \& Prevention, 41(5), 963968.

Deffenbacher, J. L., Deffenbacher, D. M., Lynch, R. S., \& Richards, T. L. (2003). Anger, aggression, and risky behavior: a comparison of high and low anger drivers. Behaviour research and therapy, 41(6), 701-718.

Handayani, D., Ophelia, R. O., \& Hartono, W. (2017). Pengaruh pelanggaran lalu lintas terhadap potensi kecelakaan pada remaja pengendara sepeda motor. Matriks Teknik Sipil, 5(3).

Sabet, F. P., Tabrizi, K. N., Khankeh, H. R., Saadat, S., Abedi, H. A., \& Bastami, A. (2016). Road Traffic Accident Victims' Experiences of Return to Normal Life: A Qualitative Study. Iranian Red Crescent medical journal, 18(4). Diperoleh dari https://www.ncbi.nlm.nih.gov/pmc/ articles/PMC4893411/

Ulleberg, P., \& Rundmo, T. (2003). Personality, attitudes and risk perception as predictors of risky driving behaviour among young drivers. Safety science, 41(5), 427443.

Y1lmaz, V., \& Çelik, H. E. (2006). Risky driving attitudes and self-reported traffic violations among Turkish drivers: The case of Eskişehir. 